Jurnal Keperawatan Silampari

Volume 2, Nomor 2, Juni 2019

e-ISSN: 2581-1975

p-ISSN: 2597-7482

DOI: https://doi.org/10.31539/jks.v2i2.517

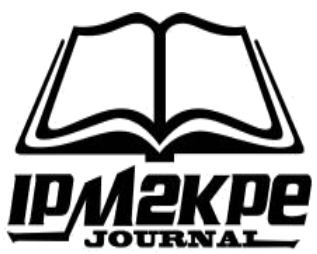

\title{
ANALISIS AKTIVITAS KONTRAKSI UTERUS DAN PERINATAL OUTCOME PADA IBU BERSALIN DENGAN INDUKSI
}

\author{
Shinta Wurdiana Rhomadona ${ }^{1}$, Melyana Nurul Widyawati ${ }^{2}$ \\ Program Kebidanan Sains Terapan Pascasarjana, Poltekkes Kemenkes Semarang ${ }^{1,2}$ \\ Shintawurdiana24@gmail.com ${ }^{1}$
}

\begin{abstract}
ABSTRAK
Tujuan penelitian ini menganalisis aktivitas kontraksi uterus dan perinatal outcome pada ibu yang melahirkan dengan induksi. Metode penelitian ini dengan desain deskriptif observasional prospektif pada $20 \mathrm{ibu}$ bersalin dengan induksi dimonitoring kontraksinya tiap 15 menit selama 10 menit secara palpasi dan di catat hasil perinatal outcomenya. Hasil penelitian ini menunjukan tren frekuensi dan durasi pada persalinan dengan induksi yang berhasil mempunyai ritme cenderung meningkat sedangkan yang gagal cenderung konstan. Berturut-turut rerata frekuensi dan durasi induksi yang berhasil 4,2 kali/10 menit dan 45,09 detik. Sedangkan pada induksi yang gagal adalah 1,92 kali/10 menit dan 25,54 detik. Simpulan, sebagian besar bbl antara 2500-4000 gram. Jenis kelamin mayoritas perempuan. Kondisi apgar score antara 7-10. 1 bayi serotinus dan tidak ada bayi yang ikterus patologis.
\end{abstract}

Kata Kunci: Aktivitas Kontraksi Uterus, Induksi Persalinan, Perinatal Outcome

\begin{abstract}
The purpose of this study is to analyze the activity of uterine contractions and perinatal outcomes in mothers who give birth by induction. The method of this study was a prospective observational descriptive design of 20 women with induction whose contractions were monitored every 15 minutes for 10 minutes by palpation and recorded perinatal outcomes. The results of this study show that the frequency and duration trends in successful induction deliveries tend to increase while those that fail tend to be constant. Successive average frequency and duration of successful induction 4.2 times / 10 minutes and 45.09 seconds. Whereas the failed induction was 1.92 times / 10 minutes and 25.54 seconds. In conclusion, most BLB is between 2500-4000 grams. The majority sex is female. Apgar score condition between 7-10. 1 baby serotinus and no baby with pathological jaundice.
\end{abstract}

Keywords: Activity of Uterine Contraction, Labor Induction, Perinatal Outcome 


\section{PENDAHULUAN}

Induksi persalinan adalah inisiasi persalinan buatan yang betujuan untuk mengeluarkan onset persalinan (Leduc et al, 2013). Frekuensi kejadian persalinan dengan induksi bervariasi tiap negara, selama beberapa dekade terakhir ini semakin banyak ibu hamil di seluruh dunia yang dilakukan induksi persalinan (WHO, 2011). Dari 30-40\% wanita yang melahirkan akan dilakukan induksi (Bomba-Opoń et al., 2017). Jika dilakukan sesuai dengan indikasi dan metode yang tepat, induksi persalinan memiliki manfaat yang besar untuk ibu bersalin dan janinya karena tujuan dari induksi persalinan itu sendiri adalah mencapai persalinan pervaginam sealami mungkin (Leduc et al., 2013). Induksi persalinan biasanya dilakukan jika risiko menunggu persalinan spontan dinilai lebih besar daripada risiko memperpendek durasi kehamilan (WHO, 2011), karena jika tetap dipertahankan dapat meningkatkan kematian dan angka kesakitan pada bayi dan ibunya seperti pada kehamilan post-term, oligohidramnion, KPD (Ketuban Pecah Dini), IUFD (Intra Uterine Fetal Death), IUGR (Intra Uterine Growth Restriction), penyakit jantung, preeklampsia dan lainya (Mozurkewich E, 2009).

Induksi persalinan tidak selamanya berhasil mengeluarkan onset persalinan secara pervaginam (Gommers et al, 2017). Kadang kala dapat pula berakhir dengan kegagalan sehingga resiko terjadi persalinan operatif meningkat secara positif dibandingkan dengan persalinan spontan (Ryan, Mc Carthy; 2016, Mc Dermott et al, 2005). Resiko lainya dapat terjadi kelelahan otot miometrium (atonia uteri), hiperstimulasi uterus, infeksi, ruptur uteri, solusio plasenta, prolaps tali pusat, kelelahan ibu, solusio plasenta, hiponatremia, hemoragik post partum dan cenderung emosional (Grobman et al, 2018; Prawirohardjo, Saifuddin, 2014; Cunningham et al, 2001; WHO, 2011). Sedangkan resiko untuk bayinya adalah terjadinya gawat janin dan meningkatnya bayi masuk NICU (Neonatus Intensif Care Unit) (Gommers et al, 2017).

Kesuksesan induksi persalinan dapat dipengaruhi beberapa hal yaitu tingkat kematangan serviks, paritas, BMI, usia ibu, perkiraan berat janin, dan diabetes (WHO, 2014). Skor bishop dikembangkan pada tahun 1964 sebagai prediktor untuk keberhasilan induksi. Sistem penilaian awal kematangan serviks menggunakan 5 determinan (dilatasi, penipisan, penurunan, posisi, dan konsistensi) yang mengaitkan nilai masing-masing determinan 0 hingga 2 atau 3 point (skor maksimal 13) (WHO, 2011). Bila terdapat seviks yang tidak matang, maka persalinan pervaginam memiliki kemungkinan yang kecil untuk berhasil (Lasmini et al, 2017).

Selama proses induksi, monitoring detak jantung janin dan aktivitas kontraksi uterus harus dipantau secara ketat agar terdeteksi apakah ada fetal distress, sindrom hiperkolesterolemia, hiperstimulasi uterus dan hiperparatiroid (Prawirohardjo and Saifuddin, 2014, WHO, 2011). Jika pada persalinan normal pengukuran aktivitas kontraksi uterus dilakukan dalam 10 menit tiap 30 menit sekali (APN, 2011) namun untuk pengukuran kontraksi pada pasien induksi dilakukan tiap 15 menit sekali (Varney et al, 2007; Leduc et al, 2013). Hal ini dilakukan salah satunya untuk menghindari terjadinya hiperstimulasi uterus sehingga harus dilakukan observasi lebih intensif. Monitoring pengukuran kontraksi dilakukan untuk mengetahui berapakah frekuensi kontraksi uterus dalam 10 menit serta durasi lamanya kontraksi uterus dalam satuan detik (APN, 2011; Santy et al, 2017). Yang dapat di interprestasikan dengan 3 tingkatan yaitu lemah, sedang dan kuat (APN, 2011).

Dalam rekomendasi WHO (World Health Organization ) tentang induksi persalinan mengatakan bahwa wanita yang menerima oksitosin, misoprostol atau 
prostaglandin perlu pengawasan yang ketat dan tidak diperbolehkan meninggalkan pasien tanpa pengawasan (WHO, 2011). Ibu bersalin dengan pemberian induksi memiliki kebutuhan lebih besar dalam monitoring untuk kontraksi daripada ibu bersalin normal (Bakker et al, 2008; Simpson, James, 2008). Sehingga dibutuhkan monitoring kontraksi uterus lebih intensif. Selama proses persalinan aktivitas otot miometrium terjadi perubahan serta peningkatan pola kontraktilitas dari kontraktur (bertahan lama dan aktivitas rendah) ke kontraksi (intensitas dan aktivitas tinggi) sehingga mengakibatkan dilatasi serviks uterus serta penurunan kepala janin (Bainuan et al, 2018). Kontraksi uterus sejak awal kala 1 atau fase laten hingga akhir kala 2 atau akhir kala 1 memiliki intensitas yang cenderung meningkat (APN, 2011). Pada kala 1 akhir frekuensi kontraksi uterus meningkat dari 2 hingga lebih dari 4 kali setiap 10 menit. Durasi kontraksi meningkat dari hanya 20 detik pada awal kala 1 sampai 60-90 detik pada kala 1 akhir atau pada awal kala II. Peningkatan regularitas aktivitas kontraksi uterus merupakan prediksi keberhasilan augmentasi oksitosin atau misoprostol dan persalinan pervaginam (Dewi, Salmiyati, 2016).

Monitoring aktivitas kontraksi uterus selama persalinan dengan induksi bertujuan untuk mendeteksi dini apakah terdapat kontraksi yang terlalu lama atau sangat kuat dan frekuensinya sering karena hal ini dapat menimbulkan masalah seperti hipoksia janin (Grobman et al., 2018). Harapanya dengan pemberian induksi dengan oksitosin ataupun misoprostol pada proses persalinan dapat membuat frekuensi dan durasi kontraksi uterus dapat meningkat, tetapi adakalanya tubuh tidak merespon terapi induksi yang diberikan sehingga menyebabkan induksi gagal. Berdasarkan survei awal, RSUD KRMT Wongsonegoro ini merupakan RS rujukan dari berbagai tempat pelayanan kesehatan di wilayah Semarang. Tercatat pada tahun 2017 di Instalansi Gawat Darurat (IGD) menerima kasus kunjungan maternal neonatal rujukan sebesar $28 \%$ atau sekitar 1361 kasus dan kasus kunjungan maternal neonatal bukan rujukan sebesar $72 \%$ atau 3516 kasus. Jenis persalinan paling banyak di RS tersebut yaitu secara pervaginam sebesar 1740 dan secara SC sebesar 1729.

\section{METODE PENELITIAN}

Penelitian ini merupakan penelitian klinis dengan menggunakan desain deskriptif observasional prospektif. Populasi penelitian ini adalah seluruh ibu bersalin dengan induksi dengan sampel berjumlah 20 responden. Penelitian ini dilakukan di RSUD K.R.M.T Wongsonegoro selama 2 bulan yaitu periode Mei hingga Juli 2018. Kriteria inklusi penelitian ini adalah ibu mendapatkan terapi induksi persalinan baik secara oral, infus atau pervaginam sesuai indikasi medis; ibu bersalin baik primipara atau multipara; kehamilan tunggal; kondisi ketuban utuh ataupun sudah pecah; kondisi jasmani dan rohani ibu sehat; serta bersedia untuk menjadi responden. Kriteria eksklusi adalah ibu yang tidak bersedia dilakukan penelitian. Instrumen yang digunakan adalah kuesioner, lembar observasi, dan stopwatch. Keseluruhan hasil data diatas dianalisa dan disajikan melalui rata-rata frekuensi dan durasi setiap responden kemudian dilakukan normalisasi data sehingga dapat disajikan melalui grafik dan dibuat kesimpulan. Sedangkan untuk perinatal outcome di sajikan melalui tabel dan narasi. 
HASIL PENELITIAN

Karakteristik Responden

Tabel. 1

Karakteristik Responden

\begin{tabular}{|c|c|c|c|c|c|}
\hline \multicolumn{2}{|c|}{ Karakteristik } & Min & Max & Mean \pm SD & $\mathrm{N}(\%)$ \\
\hline \multicolumn{2}{|l|}{ Usia Ibu (tahun) } & 22 & 41 & $30 \pm 5,02$ & \\
\hline \multicolumn{2}{|l|}{ Paritas } & 1 & 4 & $2,9 \pm 0,71$ & \\
\hline \multicolumn{2}{|l|}{$\begin{array}{l}\text { Usia Kehamilan } \\
(\mathrm{minggu})\end{array}$} & 37,2 & 42 & $40,11 \pm 1,59$ & \\
\hline \multicolumn{2}{|l|}{ TFU (cm) } & 29 & 36 & $33,5 \pm 3,12$ & \\
\hline \multicolumn{2}{|l|}{$\begin{array}{l}\text { Lama pemberian induksi } \\
\text { (jam) }\end{array}$} & 2 & 24 & $18,09 \pm 4,41$ & \\
\hline \multirow{4}{*}{$\begin{array}{l}\text { Indikasi Induksi } \\
\text { Persalinan }\end{array}$} & PEB & & & & $3(15)$ \\
\hline & Oligohidramnion & & & & $7(35)$ \\
\hline & Postdate+Oligohidramnion & & & & $5(25)$ \\
\hline & KPD & & & & $5(25)$ \\
\hline \multirow[t]{2}{*}{ Kondisi Awal Ketuban } & Utuh & & & & $13(65)$ \\
\hline & Pecah & & & & $7(35)$ \\
\hline \multirow[t]{3}{*}{ Jenis induksi } & Oksitosin Drip (OD) & & & & $14(70)$ \\
\hline & Misoprostol & & & & $0(-)$ \\
\hline & OD+Misoprostol & & & & $6(30)$ \\
\hline \multirow[t]{2}{*}{ Jenis persalinan, } & Spontan & & & & $14(70)$ \\
\hline & $\mathrm{SC}$ & & & & $6(30)$ \\
\hline \multirow[t]{2}{*}{ Keberhasilan induksi } & Berhasil & & & & $14(70)$ \\
\hline & Gagal & & & & $6(30)$ \\
\hline
\end{tabular}

Berdasarkan tabel 1 dapat dilihat bahwa dari 20 ibu bersalin dengan induksi didapatkan rerata usianya adalah $30 \pm 5,02$ tahun dengan rentan usia responden termuda adalah 22 tahun dan usia tertua adalah 41 tahun. Paritas rerata responden adalah

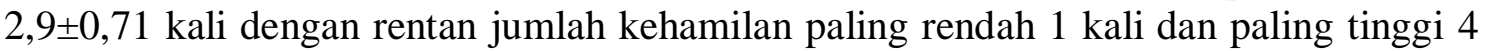
kali. Rerata usia kehamilan adalah 40,11 $\pm 1,59$ minggu dengan rentan usia kehamilan termuda 37 minggu 2 hari dan usia kehamilan tertua adalah 42 minggu. Rerata TFU responden adalah 33,5 $\pm 3,12 \mathrm{~cm}$ dengan rentan TFU terendah $29 \mathrm{~cm}$ dan tertinggi 36 $\mathrm{cm}$. Rerata lama pemberian induksi adalah 18,09 $\pm 4,41$ jam dengan rentan lama pemberian tercepat 2 jam dan terlama 24 jam. Indikasi induksi persalian pada penelitian ini paling banyak adalah oligohidramnion yaitu sebesar 35\%. Kondisi ketuban saat responden datang mayoritas masih utuh yaitu sebesar $65 \%$. Jenis induksi pada penelitian ini mayoritas menggunakan oksitosin drip yaitu sebesar 70\%. Jenis persalinan pada penelitian ini mayoritas secara spontan yaitu sebesar $70 \%$. Dari 10 responden yang dinyatakan induksi berhasil sebesar $70 \%$ dan sisanya dinyatakan gagal induksi.

\section{Hasil Analisis Aktivitas Kontraksi Uterus pada Ibu Bersalin dengan Induksi}

Tabel. 2

Distribusi Data Rerata Aktivitas Kontraksi Uterus pada Ibu Bersalin dengan Induksi

\begin{tabular}{clccc}
\hline $\begin{array}{c}\text { Keberhasilan } \\
\text { Induksi }\end{array}$ & \multicolumn{1}{c}{ Variabel } & Min & Max & Mean \pm SD \\
\hline Berhasil & Frekuensi (x/10 menit) & 1 & 7 & $4,2 \pm 1,44$ \\
\cline { 2 - 5 } $\mathrm{N}=14$ & Durasi (detik) & 20 & 60 & $45,09 \pm 8,04$ \\
\hline Gagal & Frekuensi (x/10 menit) & 1 & 3 & $1,92 \pm 0,89$ \\
\cline { 2 - 5 } $\mathrm{N}=6$ & Durasi (detik) & 15 & 35 & $25,54 \pm 1,89$ \\
\hline
\end{tabular}


Menurut tabel 2 diatas dapat diketahui bahwa dari 14 ibu bersalin dengan induksi yang dinyatakan berhasil memiliki rerata frekuensi kontraksi uterus 4,2 kali/10 menit. Rerata durasi kontraksi uterus pada persalinan kala 1 dengan induksi persalinan adalah 45,09 detik. Sedangkan dari 6 ibu bersalin dengan induksi yang gagal memiliki rerata frekuensi kontraksi uterus 1,92 kali/10 menit. Rerata durasi kontraksi uterus pada persalinan kala 1 dengan induksi persalinan adalah 25,54 detik.

Untuk mendapatkan tren data kontraksi uterus pada ibu bersalin dengan induksi didapatkan dari rerata data aktivitas kontraksi uterus yang telah diukur selama 10 menit setiap 15 menit, kemudian data tersebut dilakukan normalisasi data dengan membagi data menjadi 10 bagian. Dari setiap bagian diambil secara acak namun berurutan dari awal hingga akhir pengambilan data agar terlihat perubahan data rerata aktivitas kontraksi uterus mulai awal hingga akhir kala 1 atau hingga induksi persalinan dinyatakan gagal atau berhasil.

\section{Hasil Tren Data Frekuensi Kontraksi Uterus pada Ibu Bersalin dengan Induksi}

Frekuensi dalam penelitian adalah jumlah kontraksi pada uterus yang diobservasi selama 10 menit. Tren data frekuensi kontraksi uterus pada ibu bersalin dengan induksi dari awal kala 1 hingga akhir kala 1 atau hingga induksi persalinan dinyatakan gagal atau berhasil dapat dilihat pada gambar 1 .

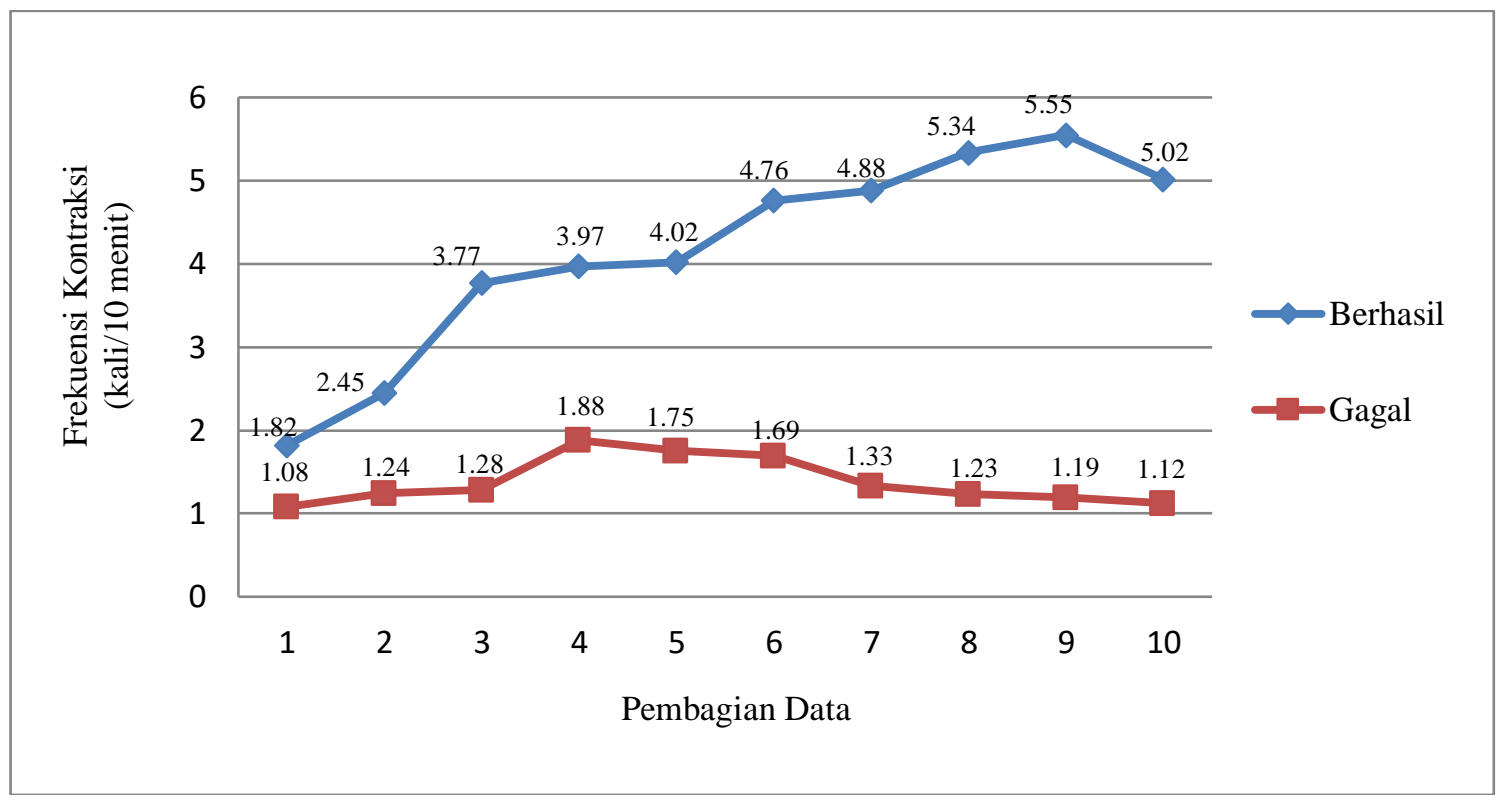

Gambar. 1

Tren data Frekuensi Kontraksi Uterus pada Ibu Bersalin dengan Induksi

Berdasarkan gambar 1 dapat diketahui bahwa frekuensi kontraksi uterus pada persalinan kala 1 dengan induksi persalinan yang berhasil memiliki kecenderungan meningkat sedangkan induksi persalinan yang gagal cenderung konstan dan memiliki nilai yang hampir sama. Frekuensi rerata maksimal pada induksi persalinan yang berhasil adalah 5,52 kali/10 menit dan frekuensi rerata minimalnya adalah 1,82 kali/10 menit. Sedangkan pada responden yang mengalami kegagalan induksi frekuensi rerata maksimal adalah 1,88 kali/10 menit dan frekuensi rerata minimal adalah 1,08 kali/10 menit. 


\section{Hasil Tren Data Durasi Kontraksi Uterus pada Ibu Bersalin dengan Induksi}

Durasi dalam peneliian ini adalah lama waktu kontrasi uterus yang terjadi selama 10 menit. Tren data durasi kontraksi uterus pada ibu bersalin dengan induksi dari awal kala 1 hingga akhir kala 1 atau hingga induksi persalinan dinyatakan gagal atau berhasil dapat dilihat pada gambar 2.

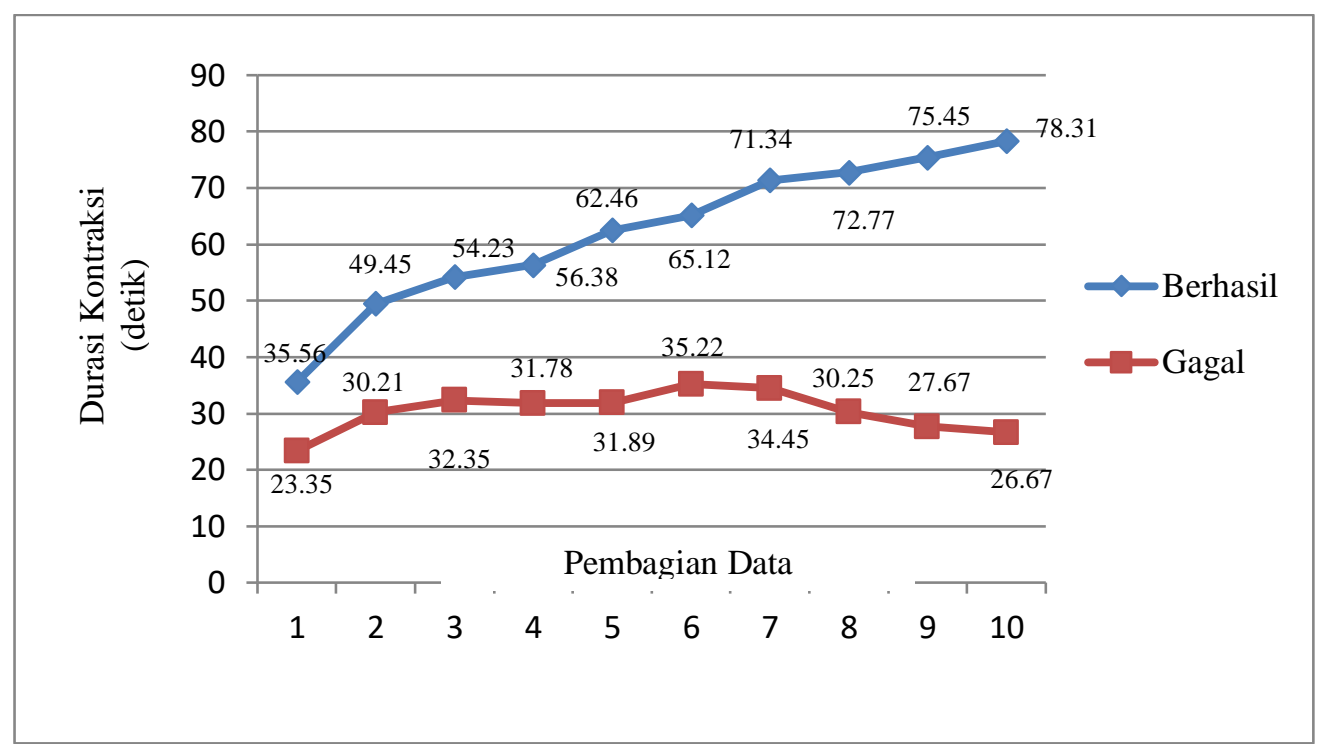

Gambar. 2

Tren data Durasi Kontraksi Uterus pada Ibu Bersalin dengan Induksi

Berdasarkan gambar 2 dapat diketahui bahwa durasi kontraksi uterus pada persalinan kala 1 dengan induksi persalinan yang berhasil memiliki kecenderungan meningkat. Sedangkan pada induksi yang dinyatakan gagal cenderung konstan. Durasi rerata maksimal pada induksi persalinan yang berhasil adalah 78,31 detik dan durasi rerata minimanya adalah 35,56 detik. Sedangkan pada responden yang mengalami kegagalan induksi durasi rerata maksimal adalah 35,22 detik dan durasi rerata minimal adalah 23,35 detik.

\section{Hasil Analisis Data Perinatal Outcome pada Ibu Bersalin dengan Induksi}

Tabel. 3

Distribusi Data Perinatal Outcome pada Ibu Bersalin dengan Induksi

\begin{tabular}{llc}
\hline \multicolumn{2}{c}{ Perinatal Outcome } & $\mathrm{N}(\%)$ \\
\hline Berat badan Lahir & $<2500$ gram & $0(0)$ \\
& 2500-4000 gram & $19(95)$ \\
\multirow{4}{*}{ Jenis Kelamin } & $>4000$ gram & $1(5)$ \\
& Laki-laki & $9(45)$ \\
Apgar Score & Perempuan & $11(55)$ \\
& $0-3$ & $1(5)$ \\
\multirow{2}{*}{ Serotinus } & $4-6$ & $3(15)$ \\
& $7-10$ & $16(80)$ \\
Ikterus Patologis & Ya & $1(5)$ \\
& Tidak & $19(95)$ \\
& Ya & $0(0)$ \\
& Tidak & $20(100)$ \\
\hline
\end{tabular}


Berdasarkan tabel 3 dapat dilihat bahwa dari 20 ibu bersalin dengan induksi didapatkan sebagian besar berat badan lahir bayi antara 2500-4000 gram yaitu sebesar 19 bayi. Jenis kelamin mayoritas perempuan yaitu sebesar 11 bayi. Kondisi apgar score saat lahir paling banyak antara 7-10 yaitu sebesar 16 bayi. Kondisi bayi saat lahir hanya 1 yang serotinus dan tidak ada bayi yang terlahir dengan ikterus patologis.

\section{PEMBAHASAN}

\section{Analisis Frekuensi Kontraksi Uterus pada Ibu Bersalin dengan Induksi}

Berdasarkan gambar 1 diketahui bahwa tren frekuensi kontraksi uterus pada 14 responden yang dinyatakan induksinya berhasil membentuk ritme dimana makin mendekati persalinan maka frekuensinya makin meningkat. Sejak pengukuran ke-1 hingga ke-9 ritme rerata frekuensi kontraksi mengalami peningkatan, namun saat pengukuran ke-10 rerata frekuensi mengalami penurunan. Hal ini dapat dijelaskan bahwa induksi persalinan dilakukan dengan tujuan menstimulasi kontraksi uterus sebelum ada tanda-tanda persalinan dengan menggunakan oksitosin atau misoprostol salah satunya.(Saifuddin, 2010; WHO, 2014) Pemberian oksitosin drip ataupun misoprostol dapat meningkatkan tonus intrauterine agar timbul kontraksi uterus.

Pada saat kala 1, oksitosin akan bekerja pada ibu dengan cara meningkatkan konsentrasi kalsium pada sel otot yang mengontrol kontraksi di uterus. Meningkatnya kadar kalsium pada sel otot berakibat pada peningkatan kontraksi uterus. (Harjanto, Muhartono, 2015) Oksitosin bekerja selektif pada otot polos uterus dan menyebabkan kontraksi ritmis pada uterus, meningkatkan frekuensi kontraksi dan meningkatkan tonus otot-otot uterus. Dengan penggunaan yang berulang dan teratur maka efek kontraksi regulernya baru akan muncul. Konsentrasi plasma dari oksitosin ini sangat dibutuhkan untuk mendapatkan kontraksi yang reguler, dimana kontraksi regular sangat diperlukan serviks untuk berdilatasi sehingga dapat menunjang keberhasilan induksi (Hadar et al, 2013).

Terjadinya penurunan frekuensi kontraksi uterus saat pengukuran ke-9 ke-10 hal ini terjadi karena kontraksi uterus dapat menurun menjelang persalinan dimana sesuai dengan teori bahwa saat pembukaan hampir lengkap (pembukaan $10 \mathrm{em}$ ) frekuensi kontraksi berlangsung lambat dan pendek atau disebut dalam fase deselarasi. (Prawirohardjo, Saifuddin, 2014) Hal ini dapat terjadi dalam waktu 2 jam dari pembukaan $9 \mathrm{~cm}$ menuju kepembukaan $10 \mathrm{~cm}$. Sedangkan pada 6 responden yang dinyatakan gagal induksi memiliki ritme frekuensi kontraksi cenderung konstan dan datar. Hal ini dapat dikatakan bahwa tubuh ibu tidak memberikan respon terhadap oksitosin ataupun misoprostol yang diberikan, sehingga tidak dapat menstimulasi otototot polos miometrium dengan adekuat. Kesuksesan induksi persalinan juga berhubungan dengan status dari serviks uteri. Bila terdapat seviks yang tidak matang persalinan pervaginam memiliki kemungkinan yang kecil untuk berhasi. Panjang, ketebalan dan konsistensi serviks juga menjadi parameter yang penting. Untuk mengukur tingkat kematangan serviks dapat menggunakan bishop skor, jika serviks skor rendah, angka kegagalan induksi persalinan maka akan meningkat. Bilai nilai bishop lebih besar atau sama dengan 9, tidak didapatkan kegagalan induksi persalinan, sebaliknya pada nilai bishop antara 5-8 didapatkan kegagalan 4,8\% dan pada nilai bishop 0-4 kegagalan sebesar 19,5\%. Beberapa penelitian didapatkan bahwa pematangan serviks menjelang induksi persalinan secara bermakna menurunkan angka kejadian seksio sesarea dari 21\%-30\% menjadi 3\%-16\%. (Lasmini et al, 2017). Oleh karena itu diperlukan agen pematangan serviks untuk melunakan serviks seperti 
prostaglandin atau misoprostol (Lasmini et al, 2017; Tenore, 2006; Ryan, McCarthy, 2016).

Hal ini terjadi karena sebagai agen farmakologi pematangan serviks yang sering digunakan seperti oksitosin atau prostaglandin, memiliki angka kegagalan induksi persalinan tinggi pada serviks yang tidak matang dan pemberian prostaglandin memberikan keuntungan untuk mematangkan serviks sekaligus sebagai inisiator kontraksi uterus sehingga angka keberhasilannya tinggi. Preparat prostaglandin yang sering digunakan adalah misoprostol karena memiliki kelebihan yaitu murah, stabil pada suhu kamar dan persiapannya mudah. Selain itu prostaglandin memiliki sifat uterotonin dan uterotropin. Sebagai uterotonin prosataglandin menyebabkan kontraksi uterus pada semua kehamilan. Sebagai uterotropin pada fase persalinan, prostaglandin menyebabkan pematangan serviks dan perkembangan gap junction (Jordan, 2011). Pada penelitian ini yang mengalami kegagalan induksi semuanya hanya menggunkan oksitosin drip yang bersifat uterotonin saja sehingga membutuhkan waktu lebih lama untuk tercapainya dilatasi serviks sehingga pada akhinya mengalami kegagalan induksi.

\section{Analisis Durasi Kontraksi Uterus pada Ibu Bersalin dengan Induksi}

Berdasarkan hasil penelitian pada gambar 2 menunjukan bahwa pada 14 responden yang induksinya berhasil mempunyai tren durasi yang cenderung semakin meningkat dengan durasi rerata maksimal adalah 78,31 detik dan durasi rerata minimanya adalah 35,56 detik. Hal ini sesuai dengan teori yang mengatakan bahwa saat fase laten kontraksi rahim berlangsung sekitar 30 hingga 45 detik dan belum teratur. Sedangkan fase aktif, kualitas kontraksi semakin adekut, durasinya lebih lama yaitu antara 30-90 detik, frekuensinya lebih sering yaitu 2-5 menit dan intenitas kontraksinya lebih kuat daripada fase laten (Saifuddin, 2010; Fraser, Cooper, 2009). Frekuensi serta durasi yang lebih lama ini mengakibatkan proses dilatasi dan penurunan kepala lebih cepat.

Pada induksi persalinan, oksitosin meningkatkan kerja sel otot polos dan memperlambat konduksi aktivitas listrik sehingga mendorong serat-serat otot berkontraksi lebih sering dan lebih kuat. Dorongan tersebut ditransmisikan ke serviks sehingga terjadilah peregangan bentuk serviks (Grobman et al, 2018; Garfield, Maner, 2007; Dania et al, 2014).s Apalagi dengan diberikanya misoprostol secara pervaginam dapat semakin membantu dalam proses pematangan serviks secara lokal pada leher rahim (Lasmini et al, 2017). Pada persalinan dengan induksi diharapkan adanya peningkatan durasi kontraksi uterus agar terjadi kemajuan persalinan. Uterus manusia relatif tidak sensitif terhadap oksitosin dan prostaglandin pada awal kehamilan dan akan cenderung responsif dengan oksitosin ketika usia kehamilan 32 minggu hingga 36 minggu (Lasmini et al, 2017). Namun adakalanya beberapa uterus di usia kehamilan tersebut secara fisiologis kurang responsif oleh karena itu adakalanya diberikan oksitosin atau prostaglandin untuk meningkatkan sensitifitas otot miometrium dalam memicu persalinan. Pemberian oksitosin atau prostaglandin (contohnya misoprostol) dapat memberikan efek dalam memperpanjang durasi kontraksi uterus sehingga mekanisme proses persalinan dalam membuka serviks dapat dengan adekuat. Oksitosin telah terbukti merangsang pelepasan prostaglandin in vitro dan in vivo (Lasmini et al, 2017). Sehingga kontraksi dapat terjadi. Namun perlu diwaspadai juga karena hal ini dapat menyebabkan kelelahan otot-otot miometrium selama proses persalinan kala I bahkan II sehingga berakibat pada banyaknya perdarahan yang dikeluarkan pada kala II persalinan (Garfield, Maner, 2007; Dania et al, 2014). 
Pada 6 responden yang gagal induksinya memiliki tren durasi kontraksi yang cenderung konstan dan menurun dengan durasi rerata maksimal adalah 35,22 detik dan durasi rerata minimal adalah 23,35 detik. Selain tingkat pematangan serviks sebagai penentu keberhasilan induksi, jumlah paritas juga merupakan faktor yang berpengaruh pada keberhasilan pematangan serviks. Pada wanita yang sudah pernah melahirkan memiliki kandungan nitrik oxida (NO) lebih tinggi dibandingkan dengan wanita yang belum pernah melahirkan (nullipara). NO dapat mengaktivasi MMPs (Matriks Metallprotease) yang berpengaruh pada proses pematangan serviks (Lasmini et al, 2017; Dewi, Salmiyati, 2016). NO mempengaruhi pematangan serviks dan berperan sebagai mediator dari inflamasi, meregulasi aktivasi MMP yang bertanggung jawab terhadap degrasi kolagen dan menginduksi produksi prostaglandin dengan mestimulasi aktivasi cyclooxygenasi (Arias, 2000).

Oksitosin dan misoprostol mempunyai efek pada aktivitas uterus responden. Oksitosin bekerja selektif pada otot polos uterus dan menyebabkan kontraksi ritmis pada uterus, meningkatkan frekuensi kontraksi yang telah ada, dan meningkatkan tonus otot-otot uterus sehingga mampu menghasilkan kontraksi yang adekuat untuk membuka serviks dan mendorong janin turun (descent) (Prawirohardjo, Saifuddin, 2014). Sedangkan misoprostol, selain memiliki efek uterotonika juga memiliki efek melunakan serviks yang berguna pada serviks dengan skor bishop kurang dari 5.

Namun ketika oksitosin atau misoprostol tersebut digunakan secara tidak tepat, maka dapat menghasilkan efek yang merugikan ibu dan janin. Efek samping yang paling ditakuti adalah disfungsui uterus, tetania uterus, ruptur uterus dan intoksifikasi air ketuban sehingga perlu pengawasan ketat (Lasmini et al, 2017; Bujold et al, 2004). Hal- hal yang perlu diperhatikan adalah pemberian oksitosin yang tepat, memastikan tidak ada kelebihan dosis dan mulai dengan dosis rendah adanya pengawasan yang memadai, pemantauan tekanan uterus, dan meningkatkan dosis pada interval yang cukup (Lasmini et al, 2017; Tang et al, 2007) Hal tersebutlah yang dapat menjaga induksi persalinan berjalan dengan aman dan bermanfaat untuk pasien.

Sedangkan sisanya pada 6 responden yang mengalami kegagalan induksi atau persalinanya dilakukan dengan SC memiliki ritme frekuensi kontraksi dan durasi kontraksi, yang cenderung konstan dan tidak meningkat. Dalam proses persalinan induksi, keadaan serviks yang belum matang dan kurang mendukung, dapat menjadi penyebab kegagalan induksi itu sendiri. Sehingga pematangan serviks sangat perlu dipertimbangkan sebelum melakukan induksi. Induksi persalinan dinyatakan gagal atau dihentikan bila jumlah kontraksi tetap $>5 \mathrm{x}$ dalam periode 10 menit atau $>15 \mathrm{x}$ dalam periode 15 menit atau didapat persisten nonreassuring fetal heart rate pattern. Jika dalam proses persalinan juga tidak adanya respon kontraksi yang adekuat dan kemajuan persalinan setelah diberikan terapi induksi beberapa kali, maka induksi persalinan dapat dinyatakan gagal atau induksi tidak respon (Dewi, Salmiyati, 2016).

Jika dilihat dari farmakokinetiknya dapat dijelaskan bahwa waktu kerja obat misoprostol yang diberikan secara oral cepat dan hampir sepenuhnya diserap saluran pencernaan. Pada dosis tunggal $400 \mu \mathrm{g}$ misoprostol oral, tingkat misoprostol plasma meningkat dengan cepat dan mencapai puncak setelah 30 menit dan menurun dengan cepat setelah 120 menit dan tetap rendah setelahnya Sedangkan jika diberikan secara vaginal lebih efektif daripada pemberian oral. Konsentrasi plasma meningkat secara bertahap setelah pemberian pervaginam, mencapai level maksimumnya setelah 70-80 menit sebelumnya perlahan menurun dengan tingkat obat yang masih dapat terdeteksi setelah 6 jam. Jika pemberian misoprostol dilakukan secara sub lingual akan 
sangat larut dan dapat larut dalam 20 menit ketika itu diletakkan di bawah lidah. Sebuah studi farmakokinetik membandingkan kinetika absorpsi rute oral, vaginal dan sublingual pemberian misoprostol. Ditemukan bahwa misoprostol sublingualwaktu terpendek ke konsentrasi puncak. Konsentrasi puncak dicapai sekitar 30 menit setelah pemberian sublingual dan oral, sedangkan berikut administrasi vagina, dibutuhkan 75 menit. Karena itu, rute sublingual dan oral memiliki waktu tercepat onset aksi. Hal Ini karena saat dilakukan secara sub lingual menghindari metabolisme pertama lewat hati. Aliran darah yang melimpah di bawah lidah dan $\mathrm{pH}$ yang relatif netral di rongga mulut dapat menjadi faktor pendukung (Tang et al, 2007; Akare, Patel, 2017).

\section{Analisis Perinatal Outcome pada Ibu Bersalin dengan Induksi}

Persalinan dengan induksi memiliki resiko untuk terjadinya gawat janin dan meningkatnya bayi masuk NICU (Neonatus Intensif Care Unit) (Gommers et al., 2017). Hasil penelitian menunjukan bahwa perinatal outcome pada $20 \mathrm{ibu}$ bersalin dengan induksi didapatkan sebagian besar berat badan lahir bayi antara 2500-4000 gram yaitu sebesar 19 bayi itu berarti hanya ada 1 bayi yang terlahir dengan berat > dari 4000 gram. Salah satu indikasi dilakuan induksi persalinan adalah kehamilan lewat bulan dimana pada kehamilan lewat bulan memiliki kemungkinan bayi yang dilahirkan memiliki berat lebih dari 4000 gram atau termasuk bayi makrosomia (Leduc et al, 2013). Ibu bersalin dengan lewat bulan memiliki resiko lebih tinggi melahirkan bayi besar yaitu 2,5-10\%. Komplikasi dari bayi makrosomia persalinan lama, disproporsi sefalopelvik dan distosia bahu dengan resiko yang dihasilkan adalah cedera ortopedi dan atau neurologis (Putri et al, 2017).

Perinatal outcome lainya pada ibu bersalin dengan induksi pada penelitian ini yaitu jenis kelamin bayi mayoritas perempuan yaitu sebesar 11 bayi. Sedangkan kondisi apgar score saat lahir paling banyak antara 7-10 yaitu sebesar 16 bayi dan ada 2 bayi yang mempunyai apgar score 4-6 (asfiksia sedang) dan 1 bayi memiliki apgar score 0-3 (asfiksia berat). Salah satu masalah kesehatan yang terjadi pada persalinan dengan induksi adalah asfiksia. Asfiksia neonatorum merupakan kondisi bayi lahir yang gagal bernafas spontan dan secara teratur segera bayi lahir. Kehamilan lewat bulan serta persalinan dengan induksi juga merupakan faktor resiko terjadinya asfiksia pada bayi baru lahir. Induksi persalinan adalah tindakan terhadap ibu hamil untuk merangsang timbulnya kontraksi. Salah satu faktor penyebab asfiksia dari ibu yaitu adanya gangguan his. Beberapa keadaan pada ibu dapat menyebabkan aliran darah melalui plasenta berkurang, sehingga aliran oksigen ke janin berkurang, hal ini dapat menyebabkan asfiksia (Meliyana, 2018).

Keterbatasan penelitian ini adalah jumlah sampel yang tidak banyak karena keterbatasan waktu penelitian sehingga hasil tidak dapat digeneralisasikan ke kelompok lain. Jumlah enumerator yang terbatas juga sehingga menjadi kendala karena tidak memungkinkan mengambil data secara bersamaan karena di lahan penelitian pernah ditemui 2-3 pasien sekaligus yang dapat di pakai sebagai responden.

\section{SIMPULAN}

Tren frekuensi kontraksi uterus pada ibu bersalin dengan induksi yang berhasil memiliki kecenderungan meningkat sedangkan induksi persalinan yang gagal cenderung datar dan memiliki nilai yang sama. Frekuensi rerata maksimal pada induksi persalinan yang berhasil adalah adalah 5,52 kali/10menit dan frekuensi rerata minimalnya adalah 1,82 kali/10 menit. Sedangkan pada responden yang mengalami kegagalan induksi 
frekuensi rerata maksimal adalah 1,88 kali/10 menit dan frekuensi rerata minimal adalah $1,08 \mathrm{kali} / 10$ menit.

Tren durasi kontraksi uterus pada ibu bersalin dengan induksi yang berhasil memiliki kecenderungan meningkat. Sedangkan pada induksi yang dinyatakan gagal cenderung konstan dan menurun. Durasi rerata maksimal pada induksi persalinan yang berhasil adalah 78,31 detik dan durasi rerata minimanya adalah 35,56 detik. Sedangkan pada responden yang mengalami kegagalan induksi durasi rerata maksimal adalah 35,22 detik dan durasi rerata minimal adalah 23,35 detik.

Dari 20 ibu bersalin dengan induksi didapatkan sebagian besar berat badan lahir bayi antara 2500-4000 gram. Jenis kelamin mayoritas perempuan. Kondisi apgar score saat lahir paling banyak antara 7-10. Kondisi bayi saat lahir hanya 1 yang serotinus dan tidak ada bayi yang terlahir dengan ikterus patologis.

\section{SARAN}

1. Saran Untuk Ibu Bersalin

Hendaknya ibu bersalin kooperatif dalam mengikuti setiap anjuran/arahan saat dilakukan monitoring aktivitas kontraksi uterus, sehingga data yang diambil akan lebih akurat dan hasilnya dapat memberikan manfaat pada ibu dalam mengurangi efek samping dari induksi persalinan sehingga pelaksanaan induksi persalinan berjalan dengan aman dan efektif.

2. Saran Untuk Tenaga Kesehatan

Diharapkan dapat digunakan sebagai acuan pada persalinan dengan induksi sehingga dapat dijadikan sebagai tanda deteksi dini jika terjadi hiperstimulasi otot pada uterus dan kegagalan induksi sehingga memudahkan penanganan selanjutnya.

3. Saran Untuk Penelitian Selanjutnya

Penelitian ini merupakan penelitian untuk mencari data dasar tentang aktivitas kontraksi uterus pada ibu bersalin dengan induksi menggunakan observasi secara manual yaitu dengan teknik perabaan (palpasi) yang memiliki bersifat subjektifitas sehingga diharapkan penelitian selanjutnya dapat meneliti tentang monitoring aktivitas kontraksi uterus pada ibu bersalin dengan induksi menggunakan alat monitoring yang memiliki hasil lebih bersifat objektif sehingga hasilnya lebih akurat dan cepat.

\section{DAFTAR PUSTAKA}

Akare, M. D. \& Patel, P. K. (2017). A Comparison of Sublingual with Vaginal Administration of Misoprostol for Induction of Labor at Term. International Journal of Reproduction, Contraception, Obstetrics and Gynecology, 6, 13981403

Apn. (2011). Asuhan Persalinan Normal dan Inisiasi Menyusui Dini. Jakarta. JNPK-kr

Arias, f. (2000). Pharmacology of Oxytocin and Prostaglandins. Clinical Obstetrics and gynecology, 43, 455-468

Bainuan, L. D., Husin, F., Anwar, A. D., Arifin, A. \& Wirakusumah, F. F. (2018). Sensitivitas, Spesifisitas dan Akurasi Pengukuran Kontraksi Uterus Kala I Fase Aktif Ibu Bersalin menggunakan Tokodinamometer. Majalah Kedokteran Bandung, 50, 29-35

Bakker, P. C., Van Rijswijk, S. \& Van Geijn, H. P. (2008). Uterine Activity Monitoring during Labor. Journal of Perinatal Medicine, 36, 184-184 
Bomba-opoń, D., Drews, K., Huras, H., Laudański, P., Paszkowski, T. P. \& Wielgoś, M. (2017). Polish Gynecological Society Recommendations for Labor Induction. Ginekologia Polska, 88, 224-234

Bujold, E., Blackwell, S. C., Hendler, I., Berman, S., Sorokin, Y. \& Gauthier, R. J. (2004). Modified Bishop's Score and Induction of Labor in Patients with a Previous Cesarean Delivery. American Journal of Obstetrics and Gynecology, $191,1644-1648$

Cunningham, G., Leveno, G., Hauth \& Wenstrom. (2001). Obstetri Williams,vol 2. Jakarta: EGC

Dania, H., Wahyono, D., \& Retnowati, S. (2014). Perbandingan Efektivitas Misoprostol Dosis $50 \mu \mathrm{G}$ dan $100 \mu \mathrm{G}$ terhadap Keberhasilan Kelahiran Induksi di RSU PKU Muhammadiyah Yogyakarta. Pharmaciana, 4

Dewi, I. P. \& Salmiyati, Z. (2016). Evaluasi Penggunaan Misoprostol pada Kehamilan Postterm di Bangsal Kebidanan RSUP dr. M. Djamil Padang. Jurnal Ipteks Terapan, 10, 170-175

Fraser, D. M. \& Cooper, M. A. (2009). Buku Ajar Bidan Myles, Edisi 14. Jakarta: EGC

Garfield, R. E. \& Maner, W. L. (2007). Physiology and Electrical Activity of Uterine Contractions. Seminars in Cell \& Developmental Biology. Elsevier, 289-295

Gommers, J. S., Diederen, M., Wilkinson, C., Turnbull, D. \& Mol, B. W. (2017). Risk of Maternal, Fetal and Neonatal Complications Associated with the Use of the Transcervical Balloon Catheter in Induction of Labour: A Systematic review. European Journal of Obstetrics and Gynecology and Reproductive Biology, 218, 73-84

Grobman, W. A., Bailit, J., Lai, Y., Reddy, U. M., Wapner, R. J., Varner, M. W., Thorp, J. M., Leveno, K. J., Caritis, S. N., Prasad, M., Tita, A. T. N., Saade, G., Sorokin, Y., Rouse, D. J., Blackwell, S. C. \& Tolosa, J. E. (2018). Defining Failed Induction of Labor. American Journal of Obstetrics and Gynecology, 218, 122.e1122.e8

Hadar, E., Melamed, N., Aviram, A., Raban, O., Saltzer, L., hiersch, L. \& Yogev, Y. (2013). Effect of an Oxytocin Receptor Antagonist (Atosiban) on Uterine Electrical Activity. American Journal of Obstetrics and Gynecology, 209, 384. E1-384. E7

Harjanto, A. R. \& Muhartono, M. (2015). Korelasi antara Pemakaian Oksitosin Drip pada Ibu dengan Angka Kejadian Hiperbilirubinemia Neonatal. Jurnal Agromedicine, 2, 278-283

Jordan, S. (2011). Farmakologi Kebidanan. Jakarta: EGC

Lasmini, P. S., Yunitra, I., \& Bachtiar, H. (2017). Perbedaan Efek Misoprostol dan Oksitosin sebagai Pematangan Serviks. Andalas Obstetric and Gynecology Journal, 2

Leduc, D., Biringer, A., Lee, L., Dy, J., Corbett, T., Duperron, L., Lange, I., Muise, S., Parish, B., \& Regush, L. (2013). Induction of Labour. Journal of Obstetrics and Gynaecology Canada, 35, 840-857

Mcdermott, I., Saade, G., Garfield, R., \& Thornton, S. (2005). Uterine EMG Activity in Women Who do and do not Progress in Labour. American Journal of Obstetrics and Gynecology, 193, s47

Meliyana, E. (2018). Hubungan Induksi Persalinan dengan Resiko Kejadian Asfiksia Neonatorum di RSUD Kabupaten Bekasi Periode September-November Tahun 2011. Jurnal Ayurveda, 1 
Mozurkewich e, C. J., Koepke, E, Keeton, K, King, V. J. (2009). Indications for Induction of Labour: a Best-Evidence Review. Pubmed, 626-36

Prawirohardjo, S. \& Saifuddin, A. B. (2014). Ilmu Kebidanan. Jakarta: Yayasan Bina Pustaka Sarwono Prawirohardjo

Putri, M. S., Titisari, I., \& Setyarini, A. I. (2017). Hubungan Usia Kehamilan dengan Komplikasi pada Bayi Baru Lahir di RS Aura Syifa Kabupaten Kediri Tahun 2017. Jurnal Ilmu Kesehatan, 6, 101-108

Ryan, R \& Mccarthy, F. (2016). Induction of Labour. Obstetrics, Gynaecology \& Reproductive Medicine, 26, 304-310

Saifuddin, A. B. (2010). Buku Acuan Nasional Pelayanan Kesehatan Maternal dan Neonatal. Jakarta: Yayasan Bina Pustaka Sarwono Prawirohardjo

Santy, T. A., Suryono \& Nurul, M. (2017). Aktivitas Kelistrikan Uterus pada Kontraksi Persalinan Kala 1. Master. Semarang Health Polytechnic

Simpson, K. R. \& James, D. C. (2008). Effects of Oxytocin-Induced Uterine Hyperstimulation during Labor on Fetal Oxygen Status and Fetal Heart Rate Patterns. American Journal of Obstetrics and Gynecology, 199, 34. E1-34. E5

Tang, O., Gemzell-Danielsson, K. \& Ho, P. (2007). Misoprostol: Pharmacokinetic Profiles, Effects on the Uterus and Side-Effects. International Journal of Gynecology \& Obstetrics, 99

Tenore, J. L. (2006). Methods for Cervical Ripening and Induction of Labor. American Family Physician, 67, 2123-2128

Varney, H., Kriebs, J. M. \& L, C. (2007). Buku Ajar Asuhan Kebidanan,Edisi 4. Jakarta: EGC

Who. (2011). Who Recommendations for Induction of Labour, Geneva: World Health Organization

Who. (2014). Who Recommendations for Augmentation of Labour, World Health organization

William A. Grobman, J. B., Yinglei Lai, UMA M. Reddy, Ronald J. Wapner, michael W. Varner, John M. Thorp, Kenneth J. Leveno, Steve N. Caritis, Mona Prasad, Alan T.N. Tita, George Saade, Yoram Sorokin, Dwight J. Rouse, Sean C. Blackwell, Jorge E. Tolosa. (2017). Defining Failed Induction of Labor, in American Journal of Obstetrics and Gynecology. American Journal of Obstetrics and Gynecology 